\title{
Fair Value and Abnormal Audit Fees
}

Tatyana Ryabova (Corresponding author)

California State University

5245 North Backer Ave M/S PB7, Fresno, CA 93740, USA

Tel: 559-278-1683 E-mail: tryabova@csufresno.edu

Keji Chen

California State University

18111 Nordhoff Street, Northridge, CA 91330, USA

Gary Taylor

University of Alabama

326 Alston Hall, Box 870220, Tuscaloosa, AL 35487, USA

\author{
Rishma Vedd \\ California State University
}

18111 Nordhoff Street, Northridge, CA 91330, USA

Received: July 31, 2018

doi:10.5296/ijafr.v8i3.13453
Accepted: August 19, 2018 Published: August 27, 2018

URL: https://doi.org/10.5296/ijafr.v8i3.13453

\begin{abstract}
Our study compares the financial reporting quality between a principles-based (i.e., fair value) and a rules-based (i.e., historical cost) accounting system. We explore a non-market based proxy of financial reporting quality: abnormal or unexplained audit fees. Utilizing a sample of European Union firms, we find that firms using a fair value accounting system have a lower level of abnormal audit fees. This result provides preliminary evidence that a fair value accounting system provides higher financial reporting quality.
\end{abstract}

Keywords: Fair value accounting, Historical cost accounting, Financial reporting quality, Abnormal audit fees 


\section{Introduction}

International Financial Reporting Standards (IFRS) allow firms to decide whether to use historical cost (HC) or fair value (FV) accounting systems for non-financial assets such as property, plant and equipment (IAS 16), intangibles (IAS 38), and investment property (IAS 40). The question remains as to whether or not one system HC or FV provides a higher degree of financial reporting quality. In this study, we use abnormal or unexplained audit fees as a non-market based proxy of financial reporting quality. We provide evidence that firms using FV accounting system have a lower degree of abnormal or unexplained audit fees suggesting that FV accounting system provides a higher level of financial reporting quality.

Barth (2007) describes why the International Accounting Standards Board (IASB) may believe that FV accounting system provides a higher degree of financial reporting quality than HC accounting system. Barth, Landsman, and Lang (2008) provide evidence that firms selecting FV accounting system record losses in a timelier manner and have a higher association between price, earnings and book value of equity. Barth (2007) identifies the lack of verifiability resulting in potential management earnings manipulation is one of the arguments against FV. However, defining earnings quality via value relevance may be problematic since the market evaluates earnings, among other pieces of information, when determining price changes. As noted by Barth et al. (2008), providing additional financial reporting quality metrics increases the validity of the findings in the ex-ante literature. We rely on this argument to use a non-market based measure as a proxy for financial reporting quality.

Hribar, Kravet, \& Wilson (2014) provide evidence that there is a positive correlation between the abnormal or unexplained audit fees (the residual) and firms with a low degree of financial reporting quality. Hribar et al. (2014) provide compelling evidence that unexplained audit fees are a useful measure of financial reporting quality as it is predictive of financial statement restatements, fraud and is uncorrelated with potential omitted correlated variables. Based on the above discussion, we utilize the abnormal or unexplained audit fees (the residual) as the measure of financial reporting quality, where larger values of the residual indicate lower financial reporting quality.

\section{Literature Review}

The debate over the relative merits of principles-based (i.e. fair value) versus rules-based (i.e. historical cost) standards has drawn considerable attention from regulators, standards-setters and accounting professionals (DiPiazza, McDonnell, Samyn, Flynn, Quigley, \& Turley, 2008). Many recent studies focused on the effect of principles-based accounting standards on financial reporting quality, as practitioners and academics try to understand the potential consequences of moving to principles-based standards under IFRS. Some studies indicate that principles-based accounting standards are likely to result in higher quality and more transparent financial reporting (Agoglia, Doupnik, \& Tsakumis, 2011; Jamal \& Tan, 2010; Segovia, Arnold, \& Sutton, 2009). In addition, some research suggests that auditors' judgment under principles-based standards, regardless of the strength of financial regulatory regime, leads to more conservative reporting when compared to the current United States 
system that has essentially rules-based standards couple with a stronger financial regulatory regime (Cohen, Krishnamoorthy, Peytcheva, \& Wright, 2013). However, some criticize that a move to principles-based standards will increase firms' exposure to litigation. The U.S. Congress issued a mandate in the Sarbanes-Oxley Act of 2002, requiring the U.S. Securities and Exchange Commission (SEC) to conduct a study of the cost of implementing more principles-based standards in the United States (SEC, 2003). Furthermore, SEC (2010) issued a proposal that would require public firms in the United States to adopt more principles-based IFRS due to "a primary concern is that the United States accounting standards have become increasingly detailed and complex. Because much of the detail and complexity results from rule-driven implementation guidance, the standards may allow companies to structure transactions around the rules, circumventing the intent and spirit of the standards" (Herrmann, Saudagaran, \& Thomas, 2006). Neither U.S. Sarbanes-Oxley Act of 2002 nor the U.S. Securities and Exchange Commission staff study provide any empirical evidence in favor of one standard system or the other or even consider how policy makers could glean such evidence (Webster \& Thornton, 2005).

\subsection{Plusses and Minuses of Rules-Based Standards (i.e. HC)}

Critics argue that the rules-based approach (i.e. historical cost) is a restricted approach where a transaction must be accounted in accordance with a rule even if the applied accounting is misleading; it does not properly help reflect firms' asset true value in the current market; it does not represent the cost to assemble future resource needs; and it is increasingly detailed and complex. HC measurement consists of recording entity specific costs at the acquisition price, and subsequently depreciating the assets over their life span. These depreciable costs are then assigned to the periods in which the assets have been used. Although HC method seems very logical, as it provides reliable and verifiable information, some concern that $\mathrm{HC}$ measurement does not help properly reflect the firms' true values in the current market, nor does it represent the cost to assemble future resource needs. "Historical costs do not provide representationally faithful measures of asset values when the market rate of depreciation (or appreciation) differs materially over time from the book rate of depreciation" (Herrmann et al., 2006). It is argued that valuating assets at HC tends to provide an outdated value, one that cannot be used to determine the company's current financial position. The argument is based that HC simply provides information of past sunk costs, which may or may not be a good indicator for current and future economic decisions. So, opponents of $\mathrm{HC}$ accounting system argue that $\mathrm{HC}$ accounting system does rely on past economic events and does not represent future cash flows (Barth, 2007; Power, 2010; Lachmann, Wöhrmann, \& Wömpener, 2011; Christensen \& Nikolaev, 2013; Magnan, Menini, \& Parbonetti, 2015).

Although HC measurement does not reflect the current market price, which influences new endeavors, it can be relied on as trustworthy (Carr, Brinker, \& Sherman, 2009). Proponents of $\mathrm{HC}$ accounting system (recording assets at their original cost) argue that $\mathrm{HC}$ accounting system provides the highest degree of reliability. The original cost is easily verified with invoices or similar documentation and, once confirmed, does not need to be re-audited. Thus, advantages of the rules-based approach include clarity in application, reduction of litigation risk, and comparability for companies in the same industry for the same rule. Moreover, the 
detailed rules and authoritative guidance also serve standard setters' and regulators' objective of reducing the opportunities of managers to use judgments to manage earnings (Benston, Bromwich, \& Wagenhofer, 2006). To the contrary, the U.S. Securities and Exchange Commission reports state,

Unfortunately, experience demonstrates that the rules-based standards often provide a roadmap to avoidance of the accounting objectives inherent in the standards. Internal inconsistencies, exceptions and bright-line tests reward those willing to engineer their way around the intent of the standards. This can result in financial reporting that is not representationally faithful to the underlying economic substance of transactions and events. In a rules-based system, financial reporting may well come to be seen as an act of compliance rather than an act of communication. Moreover, it can create a cycle of ever-increasing complexity, as financial engineering and implementation guidance vie to keep up with one another (SEC, 2003).

Essentially, the U.S. Securities and Exchange Commission report concludes that that a rules-based system is not desirable. However, in the recent study, done by Donelson, McInnis, and Mergenthaler (2016), researchers state that since litigation risk and transaction complexity are likely to remain high in the United States, the demand for rules-based standards will likely remain high as well. Donelson et.al. (2016) findings suggest that even if standards setters consciously move the U.S. accounting standards toward a less rules-based system, such a change may be short-lived. Still, disadvantages of the rules-based information include a restricted approach where a transaction must be accounted in accordance with a rule even if the applied accounting is misleading, non-comparability between different companies when the transactions are similar and increased litigation risk when an applicable rule is not followed. In addition, with the passage of time, historical prices become irrelevant in assessing an entity's current financial position (Penman, 2007). Other critics of rules-based standards pointed out that rules can become useless and, worse yet, dysfunctional when the economic environment changes or as managers create innovative transactions around them (Kershaw, 2005).

\subsection{Plusses and Minuses of Principles-Based Standards (i.e. FV)}

On the other hand, FV measurement attempts to valuate an asset based on estimates of its current market value, or the cost of that same asset if it were to be sold between two willing and able parties at the arm's length transaction. Proponents of FV accounting system argue that FV provides an updated measure of firm's assets and liabilities. However, opponents of FV accounting system argue that the assets are recorded at an exit value (the value the firm could obtain for the asset in liquidation proceedings) rather than the future cash flows generated by the firm's assets. Critics argue that these two "fair values" - exit value or present value of free cash flows - could be very different (Barth, 2007; Power, 2010; Lachman, Wöhrmann, \& Wömpener, 2011; Christensen \& Nikolaev, 2013; Magnan, Menini, $\&$ Parbonetti, 2015). Therefore, exit values might not be relevant to all financial statement users. Furthermore, FV measurement tends to create a volatile value of the assets throughout the periods in which they are held. Critics of FV argue that FV accounting has significantly 
contributed to the financial crises in the United States since the Great Depression and intensified its severity for financial institutions all around the world (Hughes \& Tett, 2008; Johnson, 2008). However, FV measurement may fulfill stakeholder's need for up-to-date information on the value of assets. Proponents argue that FV measurement for assets or liabilities reflect current market conditions and therefore provide timely information, which leads to increased transparency and prompts corrective actions (Laux \& Leuz, 2009). FV measurement allows for a current and relevant situation analysis of the financial position of the entity, without having to depend on outdated costs. Herrmann, Saudagaran, and Thomas (2006) argue that FV is superior to HC in measuring property, plant and equipment in all the qualitative characteristics other than verifiability. Such qualitative characteristics include predictive value, feedback value, timeliness, neutrality, comparability and consistency. Using FV to measure assets and liabilities is attractive according to Barth (2004) because it meets many of the Conceptual Framework's qualitative characteristics of useful financial statement information. Moreover, FV can be viewed as fulfilling a stewardship role for financial reporting because the financial statements reflect the values of assets at the firm's disposal (Barth, 2004). In addition, FASB "has required greater use of FV measurements in financial statements because it perceives that information as more relevant to investors and creditors than HC information. Such measures better reflect the present financial state of reporting entities and better facilitate assessing their past performance and future prospects. In that regard, the FASB does not accept the view that reliability should overweight relevance for financial statement measurements" (Johnson, 2005).

Some concerned, however, that standard setters do not seem to take into sufficient account that the format of standards and their contents are interdependent. In particular, the more judgment an accounting principle requires, the more difficult is it to cast it into a standard without plenty of guidance and, perhaps, exceptions (Benston et al., 2006). Although FV measurement might appear to be a better alternative, using this method causes a loss in its degree of reliability. This drawback exists because the relevant costs generated depend on management estimates, which are fully based on the information that is readily available. Opponents claim that FV is not relevant and potentially misleading for assets that are held for a long period of time (Laux \& Leuz, 2009). Most assets are hard to assign FV that reflects the price that a "willing and able" party would agree to pay, because the value does not depend on actual historical transactions but rather on estimates of the current market. Some argued that with an increased reliance on the professional judgment, implementation of principles-based standards could result in a decrease in comparability across firms (Agoglia et al., 2011). Since valuations are based on estimates and not on acquisition costs, they are at the mercy of human error and bias, which can obscure the results of the valuation estimates. FV measurement tends to create a volatile value of the assets throughout the periods in which they are held. "First, FV introduces volatility in the financial statement in "normal times," when prompt action is not needed. Second, full FV can give rise to contagion effects in times of crisis, which need to be addressed - be it in the accounting system or with prudential regulation" (Laux \& Leuz, 2009). 


\subsection{Managerial Relevance}

According to the recent research, the corporate community has limited support for FV accounting and believes that FV accounting should be used for financial instruments and disclosures only (Dichev, Graham, Harvey, \& Rajgopal, 2013). Based on the survey conducted in 2008 on opinions of CFOs of public companies in the United States with respect to the choice of FV accounting for non-financial assets, of the 238 respondents, less than $17 \%$ stated that they would use FV accounting for non-financial assets which is consistent with the findings from the European Union firms (Hlaing \& Pourjalali, 2012). Christensen and Nikolaev (2013) examine the choice between FV and HC accounting for tangible assets in a setting where market forces rather than regulators determine the outcome. In general, they find a very limited use of FV accounting. Only 3\% of sample firms prefer FV accounting for at least one asset class following IFRS adoption in Germany and the United Kingdom. Their findings indicate that FV is unlikely to become the primary valuation method for tangible assets on a voluntary basis (Christensen \& Nikolaev, 2013). Furthermore, based on latest survey done by Dichev et al. (2013), one of the CFOs states that he has been a CFO for a long time and although historically, consistent and smooth earnings would have been indications of a very well-run company, with the new accounting rules, especially with FV accounting, these ideas are no longer relevant. In many cases "one can follow the accounting rules to a $\mathrm{T}$ and in doing so the volatility blows up" (Dichev et al., 2013). Also, the results of study by Cairns, Massoudi, Taplin, and Tarca (2011) suggest a conservative approach and/or lack of incentives to use FV measurement for most companies in their sample of 228 listed companies in the United Kingdom and Australia around the time of adoption of IFRS. Interestingly, the popularity of the adoption of revaluation of Property, Plant, and Equipment (PP\&E) among Korean firms is greater compare to other countries. About $18 \%$ of publicly listed Korean companies have revalued PP\&E in the first quarter of 2009 since the reintroduction of PP\&E revaluation on December 30, 2008 as documented in Choi, Pae, Park, and Song (2013) studies.

The choice between FV and HC accounting is one of the most widely debated issues in the accounting literature (Christensen \& Nikolaev, 2013). Nevertheless, the evidence on the impact of principles-based versus rules-based standards on financial reporting quality is mixed. Though FV accounting is viewed as "more up to date", it appears to be quite complex for many external users and the financial statement preparers. Our study will be valuable addition to earlier published debate and literature by investigating whether FV accounting measurement produces higher financial reporting quality. We explore a non-market based proxy of financial reporting quality: abnormal or unexplained audit fees.

\section{Research Method}

Of particular importance to this paper is a study by Hribar et al. (2014) who propose a summary measure of financial reporting quality - audit fees. Hribar et al. (2014) look at the correlation between the unexplained audit fees (UAF) and other empirical measures of quality and find a positive correlation. The authors use residual or the unexplained audit fees of the Picconi and Reynolds (2012) model as their measure of financial reporting quality, 
where larger values of the residual indicate lower financial reporting quality. After they estimate UAF, they apply Dechow and Dichev's (2002) measure of accounting accrual quality to test whether UAF is associated with existing based measures of information quality. The authors state that, "an important implication of our study is that UAF can be used to test hypotheses about the determinants and economic consequences of accounting quality." In addition, the authors derive a general definition of financial reporting quality, "accounting quality is the extent to which accounting information accurately reflects the company's current operating performance, is useful in predicting future performance, and helps assess firm value" (Hribar et al., 2014). In addition, it is important to mention that financial reporting quality is intertwined with the audit quality. DeFond and Zhang (2014) define higher audit quality as greater assurance of high financial reporting quality. There is a large body of literature providing evidence of differential audit quality beyond the legal and professional minimum including firm size, industry specialization, office characteristics, and cross-country differences in legal systems and auditor liability exposure (Francis, 2004). The most commonly used outcome measures to infer audit quality are auditor litigation, audit reports, investigations by security regulators, earnings restatements, and earnings quality measures. There are several important reasons to examine UAF as the indication of financial reporting quality. Auditors have inside knowledge of firm's financial reporting system and its innate characteristics. A notion that the auditors' responsibility extends to assure financial reporting quality is consistent with International Standards on Auditing, which require auditors to "form an opinion on whether the financial statements are prepared, in all material respects, in accordance with the applicable financial reporting framework" (International Standards on Auditing 2015). Even though the auditors' opinion itself does not contain a lot of information, but the fees charged by auditors will reflect the quality of financial reporting. For example, Ettredge, $\mathrm{Xu}$, and $\mathrm{Yi}$ (2014) study is consistent with the view that audit risk and effort increase with the extent of FV assets, they provide evidence that auditors charge more for higher proportions of assets held in the form of fair-valued assets. According to Bratten, Gaynor, McDaniel, Montague, and Sierra (2013), FV data is more difficult to audit than many other types of data. Their research notes that FV lack objective verifiability so that auditing FV data is less structured than many auditor tasks. Auditing standards allow use of considerable professional judgment, further complicating audits of FV data. Bratten et al. (2013) also claim that auditors most frequently follow a single approach: reviewing and testing managers' models and assumptions. They argue that a shortcoming of this approach is that even small changes in one assumption can materially affect reported income. Also, Benston (2008) states that unlike the situation for historical costs, many of the fair exit values illustrated by FASB are derived from managers' determinations of the amounts for which assets could be sold and liabilities assumed. It probably will be difficult if not impossible for external auditors to validate these numbers or even challenge managements' estimates. Moreover, Goncharov, Ried, and Sellhorn (2014) investigate the effect of FV reporting and its attributes on audit fees. Their sample include the European real estate industry for the period 2001-2008 that mandatory adopted IFRS on January 1, 2005 under which it is optional to report real estate property using FV accounting measurements. They find that firms reporting property assets at FV have the lower audit fees compare to those employing 
depreciated cost. The authors conclude that "depreciated cost-based reporting has two features that introduce potential complexity and uncertainty into the auditing process in the real estate industry: component depreciation and impairment testing" (Goncharov et al., 2014). Initially, they examine if the audit fees have been changed when the firms have to switch from HC to FV. Then, the authors use the European Union real estate firms in the post-IFRS adoption period (2005 - 2008). The results of their research suggest that FV could lead to lower audit fees for real estate firms in Europe. Maksymov, Nelson and Kinney (2012) point out that "despite the importance of FV in today's financial reporting environment, relatively little research has addressed auditing FV." Still, it is not often noted in prior literature about using UAF or abnormal audit fees as the measure of financial reporting quality.

\subsection{Estimating Unexplained Audit Fees (UAF) or Abnormal Audit Fees}

Based on the above discussion, we utilize the residual or UAF (abnormal audit fees) as the measure of financial reporting quality, where larger values of the residual indicate lower financial reporting quality. The audit fee research attempts to associate audit fees with a set of predictor variables. The following logarithmic model has become a standard in the estimating auditing fee research as Hay, Knechel, and Wong (2006) point out in their studies:

$$
\ln f_{i}=b_{0}+b_{0} \ln A_{i}+\sum b_{k} g_{i k}+\sum b_{e} g_{i e}+e_{i}
$$

where $\ln f_{i}$ is the natural $\log$ of the audit fee, $\ln A_{i}$ is the natural $\log$ of a size measure (usually total assets), and $\sum b_{k} g_{i k}$ and $\sum b_{e} g_{i e}$ are two groups of potential fee drivers. Most papers using this approach have addressed one (or a few) specific independent variable(s), so the resulting regression model is usually presented as a series of control variables that have been shown to be significant in prior studies, plus the experimental variables that are being added (Hay et al., 2006).

The subsequent logarithmic audit fee model that associates logged audit fees (Audit Fees) with logged assets and other predictor variables has become the accepted standard in the accounting literature. We limit the regression to four common independent variables in current audit fee models as the European firms are not subject to Sarbanes-Oxley Act of 2002 as the United States firms: size (Total Assets), the quick ratio (QUICK), return on assets (ROA), and audit firm size (AUDSIZE), an indicator variable equals to one when the firm's auditor is a member of the Big 4 and zero otherwise).

$$
\begin{aligned}
L N(\text { Audit Fees }) & =\beta_{0}+\beta_{1} L N(\text { Total Assets })+\beta_{2} Q U I C K \\
& +\beta_{3} R O A+\beta_{4} A U D S I Z E+\beta_{5} S O X+\Phi
\end{aligned}
$$

According to Picconi and Reynolds (2012), the strongest predictor of Audit Fees is Total Assets. Figures 1A and 1B (in the appendix) graphically illustrate the associations between fees and assets, and $\log$ of fees and $\log$ of assets, respectively. Logarithmically transforming variables in a regression model is a very common way to handle situations where a non-linear relationship exists between the independent and dependent variables as well as a highly skewed variable into one that is more approximately normal (Benoit, 2011). In our research, 
unlike previous studies, we utilize the residual or UAF modeled by Francis (1984) and suggested by Picconi and Reynolds (2012) as the measurement of financial reporting quality, where larger values of the residual indicate lower financial reporting quality for non-financial assets.

Our study contributes to the literature in several ways. As the European Union firms could switch from HC to FV, following mandatory IFRS adoption in the Europe Union on January 1,2005 , it provides a good groundwork to measure financial reporting quality of two sets of firms that has not been done in prior literature. Unlike previous studies that focus on the effect of FV on the amount of audit fees; this paper focuses on abnormal audit fees as the measurement of financial reporting quality. We apply UAF or abnormal audit fees (residual) to measure financial reporting quality, proposed by Hribar et al. (2014) to determine whether FV accounting produces higher financial reporting quality, which leads to increased relevance, and higher quality of principle-based approach of standard setting. Our overall findings contribute to the debate over the relative merits of principle (fair value) versus rules-based (historical cost) standards.

\section{Results and Discussion}

European Union firms were able to switch to FV accounting system from $\mathrm{HC}$ accounting system based on the mandatory adoption of IFRS on January 1, 2005 (Daske, Hail, Leuz, \& Verdi, 2008). From the Datastream database, we identify 3,909 HC and 453 FV firm-year observations from 2005 through 2013. We first estimate the regression below to obtain the abnormal or unexplained audit fees (residual values) for each of the two samples.

$$
\begin{aligned}
\text { LN }(\text { AUDIT FEES })_{t} & =\beta_{0}+\beta_{1} L N(\text { TOTAL ASSETS })_{t} \\
& +\beta_{2} \mathrm{QUICK}_{\mathrm{t}}+\beta_{3} \mathrm{ROA}_{\mathrm{t}}+\beta_{4} \mathrm{BIG}_{\mathrm{t}}+\varepsilon
\end{aligned}
$$

Where:

LN $($ AUDIT FEES $)=$ natural log of audit fees for period $t$

LN $($ TOTAL ASSETS $)=$ natural log of total assets at the end of period $t$,

QUICK = quick ratio (current assets-inventory) divided by current liabilities at the end of period $\mathrm{t}$,

$\mathrm{ROA}=$ return on assets ratio (net income divided by average assets for period $\mathrm{t}$ ) at the end of period $\mathrm{t}$,

BIG4 = 1 if the firm is audited by a Big 4 accounting firm, 0 otherwise.

Next, we compare the magnitudes of the residual mean of square, which captures the average abnormal or unexplained audit fees for the firms within each sample during that year, for the two samples of the European Union firms by year; and then a paired t-test is used to compare two sample means from 2005 to 2013. Tables 1 and 2 presents the residuals from the regression used to obtain the abnormal or unexplained audit fees for $\mathrm{HC}$ and FV firms by year. The average unexplained audit fees of $\mathrm{HC}$ firms is higher than that of FV firms in each 
of the nine years, while the average unexplained or abnormal audit fees of both samples are generally decreasing over time. The results suggest that, while financial reporting quality is increasing over time for both samples, financial reporting quality for FV firms is consistently higher than that of HC firms. Table 1 compares the average abnormal or unexplained audit fees of HC firms to that of FV firms over the nine years. The mean difference between the two average abnormal or unexplained audit fees over the nine years is 0.34 (HC higher than FV) and significant with a $t$-value of 3.191 and a $p$-value of 0.013 (2-tailed). Together, the results indicate that FV accounting system produces significantly higher financial reporting quality for reporting non-financial assets than HC accounting system. In Tables 1 and 2, we present the empirical results of the abnormal audit fee model.

Table 1. Descriptive and inferential statistics for the abnormal audit fees

\begin{tabular}{|c|c|c|c|c|c|c|}
\hline \multirow[b]{2}{*}{ Years } & \multicolumn{2}{|c|}{ Sample Size } & \multicolumn{2}{|c|}{$\begin{array}{l}\text { Residual Mean of } \\
\text { Square }\end{array}$} & \multicolumn{2}{|c|}{$\begin{array}{l}\text { Paired Samples Test - the residual } \\
\text { mean square or abnormal audit fees }\end{array}$} \\
\hline & $\mathrm{HC}$ & $\mathrm{FV}$ & $\mathrm{HC}$ & $\mathrm{FV}$ & HC Mean & 1.1590113 \\
\hline 2005 & 311 & 65 & 1.761 & 1.159 & FV Mean & 0.8211981 \\
\hline 2006 & 344 & 57 & 2.066 & 1.063 & HC Std. Deviation & 0.4435867 \\
\hline 2007 & 385 & 49 & 1.160 & 0.687 & FV Std. Deviation & 0.1989331 \\
\hline 2008 & 417 & 68 & 0.935 & 0.621 & $H C-F V$ pair & \\
\hline 2009 & 456 & 57 & 0.856 & 0.674 & Mean & 0.3378132 \\
\hline 2010 & 478 & 53 & 0.863 & 0.700 & Std. Deviation & 0.3175439 \\
\hline 2011 & 505 & 52 & 0.962 & 0.831 & Std. Error Mean & 0.105848 \\
\hline 2012 & 510 & 33 & 0.911 & 0.985 & $t$ & 3.1914951 \\
\hline 2013 & 503 & 19 & 0.918 & 0.670 & $d f$ & 8 \\
\hline Total & $\mathbf{3 , 9 0 9}$ & 453 & & & Sig. (2-tailed) & 0.012775 \\
\hline
\end{tabular}




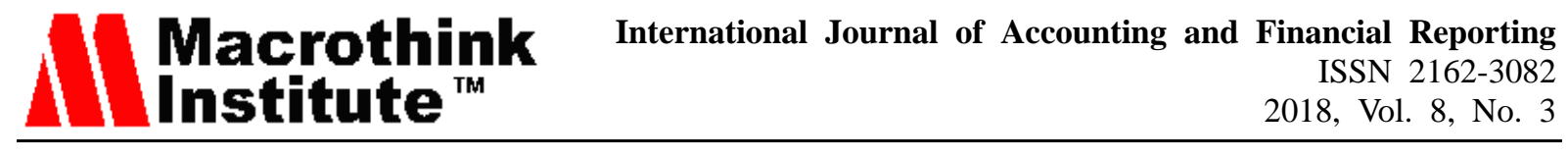

Table 2. Summary inferential statistics for the abnormal audit fee model

\begin{tabular}{|c|c|c|c|c|c|c|c|c|c|}
\hline $\mathrm{HC}$ firms & 2005 & 2006 & 2007 & 2008 & 2009 & 2010 & 2011 & 2012 & 2013 \\
\hline$R$ Square & 0.50 & 0.45 & 0.60 & 0.64 & 0.67 & 0.64 & 0.63 & 0.62 & 0.63 \\
\hline Adjusted $R$ Square & 0.50 & 0.44 & 0.60 & 0.63 & 0.66 & 0.64 & 0.62 & 0.62 & 0.63 \\
\hline Sig. & 0.00 & 0.00 & 0.00 & 0.00 & 0.00 & 0.00 & 0.00 & 0.00 & 0.00 \\
\hline Residual & 1.76 & 2.07 & 1.16 & 0.94 & 0.86 & 0.86 & 0.96 & 0.91 & 0.92 \\
\hline Sig. - (Constant) & 0.00 & 0.00 & 0.00 & 0.00 & 0.00 & 0.00 & 0.00 & 0.00 & 0.00 \\
\hline Sig. - log_TA & 0.00 & 0.00 & 0.00 & 0.00 & 0.00 & 0.00 & 0.00 & 0.00 & 0.00 \\
\hline Sig. - Quick Ratio & 0.10 & 0.50 & 0.45 & 0.33 & 0.12 & 0.07 & 0.05 & 0.06 & 0.00 \\
\hline Sig. - ROA & 0.11 & 0.05 & 0.23 & 0.06 & 0.03 & 0.17 & 0.10 & 0.79 & 0.43 \\
\hline Sig. - Auditor & 0.39 & 0.39 & 0.24 & 0.46 & 0.15 & 0.14 & 0.86 & 0.45 & 0.48 \\
\hline FV firms & 2005 & 2006 & 2007 & 2008 & 2009 & 2010 & 2011 & 2012 & 2013 \\
\hline R Square & 0.52 & 0.55 & 0.67 & 0.62 & 0.70 & 0.75 & 0.67 & 0.68 & 0.67 \\
\hline Adjusted $R$ Square & 0.49 & 0.52 & 0.64 & 0.60 & 0.68 & 0.73 & 0.65 & 0.64 & 0.58 \\
\hline Sig. & 0.00 & 0.00 & 0.00 & 0.00 & 0.00 & 0.00 & 0.00 & 0.00 & 0.00 \\
\hline $\begin{array}{l}\text { Residual Mean } \\
\text { Square }\end{array}$ & 1.16 & 1.06 & 0.69 & 0.62 & 0.67 & 0.70 & 0.83 & 0.99 & 0.67 \\
\hline Sig. - (Constant) & 0.19 & 0.35 & 0.05 & 0.00 & 0.00 & 0.00 & 0.00 & 0.01 & 0.01 \\
\hline Sig. - log_TA & 0.00 & 0.00 & 0.00 & 0.00 & 0.00 & 0.00 & 0.00 & 0.00 & 0.00 \\
\hline Sig. - Quick Ratio & 0.18 & 0.17 & 0.92 & 0.75 & 0.49 & 0.23 & 0.78 & 0.21 & 0.16 \\
\hline Sig. - ROA & 0.59 & 0.35 & 0.04 & 0.85 & 0.89 & 0.57 & 0.28 & 0.67 & 0.95 \\
\hline Sig. - Auditor & 0.73 & 0.14 & 0.95 & 0.39 & 0.83 & 0.91 & 0.82 & 0.44 & 0.26 \\
\hline
\end{tabular}




\section{MInstitute ${ }^{\text {Mink }}$}

International Journal of Accounting and Financial Reporting

ISSN 2162-3082

2018, Vol. 8, No. 3

Consistent with the results presented in Tables 1 and 2 , we find that firms using a FV accounting system have a significantly lower level of abnormal or unexplained audit fees. This result suggests that FV accounting system has a higher quality financial reporting system as compared to $\mathrm{HC}$ firms. This is particularly interesting given the increased difficulty in auditing fair value estimates as compared to assets recorded in $\mathrm{HC}$ accounting system. It is apparent that the sample sizes are dramatically different. The sample size for HC firms varies from 311 to 510 firms and the sample size for FV firms varies from 19 to 68 firms across the nine years from 2005 - 2013. To ensure that the results are not driven by the difference between sample sizes, two matching samples for $\mathrm{HC}$ and FV firms are formed based on industry and total assets for the first year of mandatory adoption of IFRS. Due to the restriction of matching industry and total assets, each sample size is reduced to 45 . The regression used to obtain the unexplained audit fees (UAF) is re-estimated for these two samples. Table 3 provides the results for the HC firms and FV firms, respectively. Consistent with the results reported in Tables 1 and 2 for the whole sample, the average abnormal or unexplained audit fees of HC firms (3.666) is much higher than that of FV firms (1.291), which indicates that FV firms have higher financial reporting quality than $\mathrm{HC}$ firms do.

Table 3. Inferential statistics for the residual mean square for abnormal audit fees

\begin{tabular}{llllll} 
& \multicolumn{2}{c}{ Sample Size } & & \multicolumn{2}{c}{ Residual Mean of Square } \\
\cline { 2 - 3 } \cline { 5 - 6 } Years & HC & FV & & HC & FV \\
2005 & 45 & 45 & & 3.666 & 1.291
\end{tabular}

\section{Summary and Conclusion}

In this study, we provide evidence relating to the financial reporting quality of firms using $\mathrm{HC}$ versus FV accounting reporting systems. Prior studies have compared the value relevance of earnings and book value for firms using $\mathrm{HC}$ and $\mathrm{FV}$ accounting reporting systems to evaluate financial reporting quality (Barth et al. 2008). We provide additional evidence relating to financial reporting quality by assessing a non-market based proxy for financial reporting quality - the abnormal or unexplained audit fees. We find that firms using FV accounting systems have lower abnormal audit fees. These results suggest that FV accounting systems are a higher quality financial reporting.

The results of this study should be informative to both academics and regulators. We provide additional evidence that FV accounting system is of higher quality than a reporting system using $\mathrm{HC}$ accounting system. Future research can provide further insights into financial reporting quality by investigating additional proxies of financial reporting systems such as the rate of fraud between the two accounting systems. Another interesting avenue of research would be to investigate abnormal audit fees before and after a firm chooses to switch from $\mathrm{HC}$ to FV accounting system. 


\section{Acknowledgement}

This research did not receive any specific grant from funding agencies in the public, commercial, or not-for-profit sectors.

\section{References}

Agoglia, C., Doupnik T., \& Tsakumis, G. (2011). Principles-based versus rules-based accounting standards: the influence of standard precision and audit committee strength on financial reporting decisions. The Accounting Review, 86(3), 747-767.

Barth, M. E. (2004). Fair values and financial statement volatility. The Market Discipline Across Countries and Industries, 323-333.

Barth, M. E. (2007). Standard-setting measurement issues and the relevance of research. Accounting and Business Research, 37(3), 7-15.

Barth, M. E., Landsman, W. R., \& Lang, M. H. (2008). International accounting standards and accounting quality. Journal of Accounting Research, 46(3), 467-498.

Benoit, K. (2011). Linear regression models with logarithmic transformations. London School of Economics, London.

Benston, G. J. (2008). The shortcomings of fair-value accounting described in SFAS 157. Journal of Accounting and Public Policy, 27(2), 101-114.

Benston, G. J., Bromwich, M., \& Wagenhofer, A. (2006). Principles - versus rules - based accounting standards: the FASB's standard setting strategy. Abacus, 42(2), 165-188.

Bratten, B., Gaynor, L. M., McDaniel, L., Montague, N. R., \& Sierra, G. E. (2013). The audit of fair values and other estimates: The effects of underlying environmental, task, and auditor-specific factors. Auditing: A Journal of Practice \& Theory, 32(sp1), 7-44.

Cairns, D., Massoudi, D., Taplin, R., \& Tarca, A. (2011). IFRS fair value measurement and accounting policy choice in the United Kingdom and Australia. The British Accounting Review, 43(1), 1-21.

Carr, J., Brinker, T. M., \& Sherman, W. R. (2001). International Accounting Standards: The History and Inevitable Future. St. Joseph's University Press (WORKING PAPER).

Choi, T. H., Pae, J., Park, S., \& Song, Y. (2013). Asset revaluations: motives and choice of items to revalue. Asia-Pacific Journal of Accounting \& Economics, 20(2), 144-171.

Christensen, H. B., \& Nikolaev, V. V. (2013). Does fair value accounting for non-financial assets pass the market test? Review of Accounting Studies, 18(3), 734-775.

Cohen, J., Krishnamoorthy, G., Peytcheva, M., \& Wright, A. (2013). How does the strength of the financial regulatory regime influence auditors' judgments to constrain aggressive reporting in a principles-based versus rules-based accounting environment? Accounting Horizons, 27(3), 579-601. 


\section{I Macrothink}

International Journal of Accounting and Financial Reporting

ISSN 2162-3082 2018, Vol. 8, No. 3

Daske, H., Hail, L., Leuz, C., \& Verdi, R. (2008). Mandatory IFRS reporting around the world: Early evidence on the economic consequences. Journal of Accounting Research, 46(5), $1085-1142$.

Dechow, P. M. \& I. D. Dichev (2002). The quality of accruals and earnings: the role of accrual estimation errors. The Accounting Review, 77(Supplement), 35-59.

DeFond, M., \& Zhang, J. (2014). A review of archival auditing research. Journal of Accounting and Economics, 58(2), 275-326.

Dichev, I., Graham, J., Harvey, C., \& Rajgopal, S. (2013). Earnings quality: Evidence from the field. Journal of Accounting \& Economics, 56(2/3), 1-33.

DiPiazza, S., McDonnell, D., Samyn, F., Flynn, T., Quigley, J., \& Turley, J. (2008, January). Principles-based accounting standards. Global Public Policy Symposium. Retrieved August 19 , 2018 , from http://pwc.blogs.com/corporatereporting/files/principlesbased_accounting_standards.pdf

Donelson, D. C., McInnis, J., \& Mergenthaler, R. D. (2016). Explaining Rules - Based Characteristics in US GAAP: Theories and Evidence. Journal of Accounting Research, 54(3), 827-861.

Ettredge, M. L., Xu, Y., \& Yi, H. S. (2014). Fair value measurements and audit fees: evidence from the banking industry. A Journal of Practice \& Theory, 33(3), 33-58.

Francis, J. R. (1984). The effect of audit firm size on audit prices: A study of the Australian market. Journal of Accounting and Economics, 6(2), 133-151.

Francis, J. R. (2004). What do we know about audit quality? The British Accounting Review, $36(4), 345-368$.

Goncharov, I., Riedl, E. J., \& Sellhorn, T. (2014). Fair value and audit fees. Review of Accounting Studies, 19(1), 210-241.

Hay, D. C., Knechel, W. R., \& Wong, N. (2006). Audit Fees: A Meta - analysis of the Effect of Supply and Demand Attributes. Contemporary Accounting Research, 23(1), 141-191.

Herrmann, D., Saudagaran, S. M., \& Thomas, W. B. (2006). The quality of fair value measures for property, plant, and equipment. Accounting Forum, 30(1), 43-59.

Hlaing, K. P., \& Pourjalali, H. (2012). Economic reasons for reporting property, plant, and equipment at fair market value by foreign cross-listed firms in the United States. Journal of Accounting, Auditing \& Finance, 27(4), 557-576.

Hribar, P., Kravet, T., \& Wilson, R. (2014). A new measure of accounting quality. Review of Accounting Studies, 19(1), 506-538.

Hughes, J., \& Tett, G. (March 13, 2008). An Unforgiving Eye: Bankers Cry Foul Over Fair Value Accounting. Retrieved August 19, 2018, from https://www.ft.com/content/19915bfc-f137-11dc-a91a-0000779fd2ac 


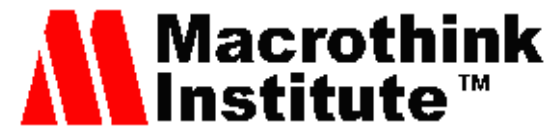

International Journal of Accounting and Financial Reporting ISSN 2162-3082 2018, Vol. 8, No. 3

IAS 16. Iasplus.com. (2018). IAS 16 - Property, Plant and Equipment. Retrieved August 19, 2018, from https://www.iasplus.com/en/standards/ias/ias16

IAS 38 Iasplus.com. (2018). IAS 38 - Intangible Assets. Retrieved August 19, 2018, from https://www.iasplus.com/en/standards/ias/ias38

IAS 40 Iasplus.com. (2018). IAS 40 - Investment Property. Retrieved August 19, 2018, from https://www.iasplus.com/en/standards/ias/ias40

IAS 8. Iasplus.com. (2018). IAS 8 - Accounting Policies, Changes in Accounting Estimates and Errors. Retrieved August 19, 2018, from https://www.iasplus.com/en/standards/ias/ias8

International Standards on Auditing 700 (2015). International Standards on Auditing (ISA) 700 (Revised), Forming an Opinion and Reporting on Financial Statements. Retrieved August 19, 2018, from http://www.ifac.org/publications-resources/international-standard-auditing-isa-700-revised-fo rming-opinion-and-reporting

Jamal, K., \& Tan, H. T. (2010). Joint effects of principles-based versus rules-based standards and auditor type in constraining financial managers' aggressive reporting. The Accounting Review, 85(4), 1325-1346.

Johnson, L. T. (2005, February 28). Relevance and reliability. The FASB Report. Retrieved August 19, 2018, from http://www.fasb.org/articles\&reports/relevance_and_reliability_tfr_feb_2005.pdf

Johnson, S. (2008, March 19). The Fair-value Blame Game. CFO.com. Retrieved August 19, 2018, from http://ww2.cfo.com/accounting-tax/2008/03/the-fair-value-blame-game/

Kershaw, D. (2005). Evading Enron: taking principles too seriously in accounting regulations. Modern Law Review, 68(4).

Lachmann, M., Wöhrmann, A., \& Wömpener, A. (2011). Acquisition and integration of fair value information on liabilities into investors' judgments. Review of Accounting \& Finance, $10(4), 385-410$.

Laux, C., \& Leuz, C. (2009). The crisis of fair-value accounting: Making sense of the recent debate. Accounting, Organizations and Society, 34(6), 826-834.

Magnan, M., Menini, A., \& Parbonetti, A. (2015). Fair value accounting: Information or confusion for financial markets? Review of Accounting Studies, 20(1), 559-591.

Maksymov, E. M., Nelson, M. W., \& Kinney, W. R. Jr. (2012). Effects of procedure frame, procedure verifiability, and audit efficiency pressure on planning audits of fair values. Johnson School Research Paper Series, (20-2012).

Penman, S. H. (2007). Financial reporting quality: is fair value a plus or a minus? Accounting and Business Research, 37(sup1), 33-44. 


\section{Mll Macrothink}

International Journal of Accounting and Financial Reporting

ISSN 2162-3082 2018, Vol. 8, No. 3

Picconi, M., \& Reynolds, J. K. (2012). Audit fee theory and estimation: A consideration of the log-log audit fee model. Indiana University working paper.

Power, M. (2010). Fair value accounting, financial economics and the transformation of reliability. Accounting and Business Research, 40(3), 197-210.

Securities and Exchange Commissions (SEC). (2003). Study Pursuant to Section 108 (d) of the Sarbanes-Oxley Act of 2002 on the adaptation by the United States financial reporting system of a principles-based accounting system. Retrieved August 19, 2018, from http://sec.gov/news/studies/principlesbasedstand.htm

Securities and Exchange Commissions (SEC). (2010). Commissions Statement in support of Convergence and Global Accounting Standards. Retrieved August 19, 2018, from http://www.sec.gov/rules/other/2010/33-9109.

Segovia, J., Arnold, V., \& Sutton, S. (2009). Do principles-vs. rules-based standards have a different impact on U.S. auditors decisions?. Advances in Accounting Behavioral Research, $12,61-84$

Webster, E., \& Thornton, D. B. (2005). Earnings Quality under Rules - versus Principles based Accounting Standards: A Test of the Skinner Hypothesis. Accounting Perspectives, 4(2), 167-192.

\section{Appendix}

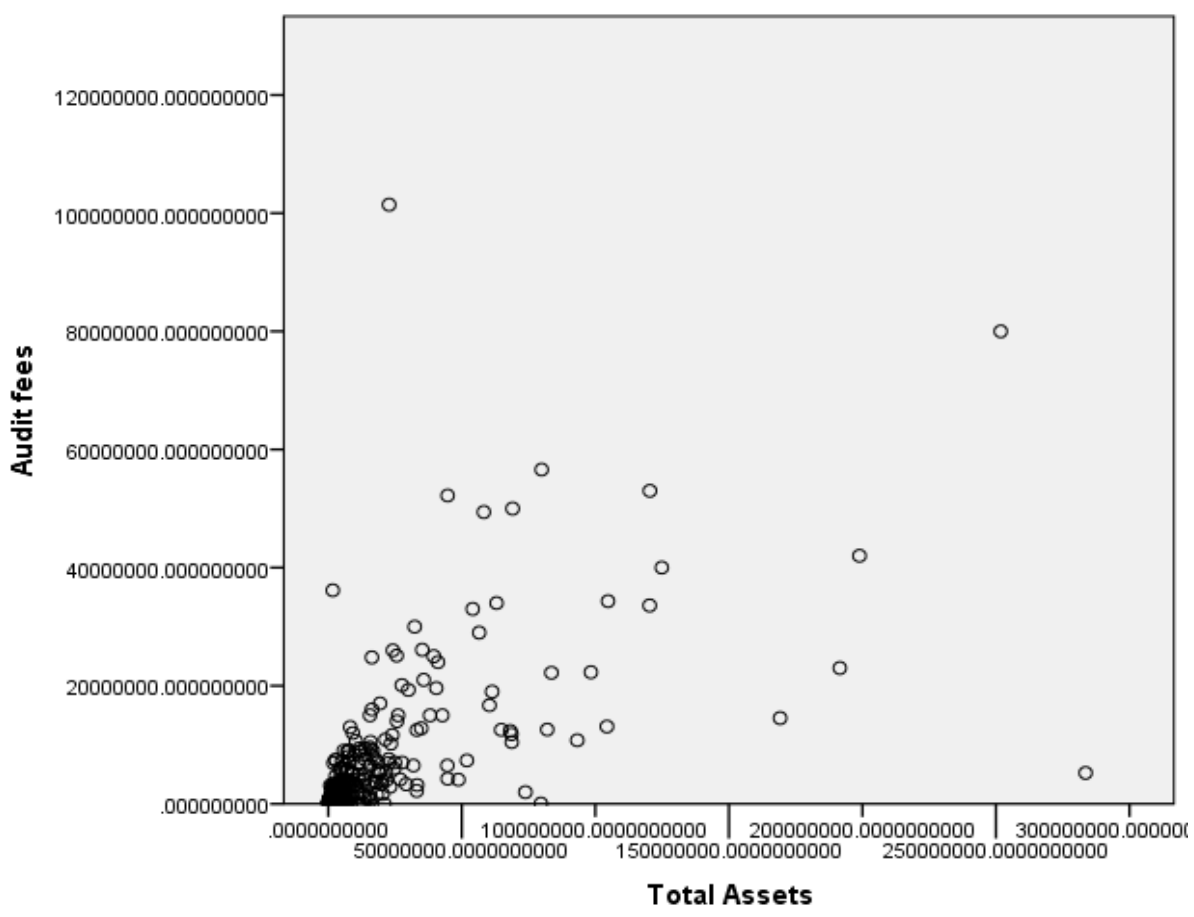

Figure 1A. Audit fees vs. total assets 


\section{\begin{tabular}{rr} 
Macrothink & International Journal of Accounting and Financial Reporting \\
Instrite & ISSN 2162-3082 \\
TM & 2018, Vol. 8, No. 3 \\
\hline
\end{tabular}}

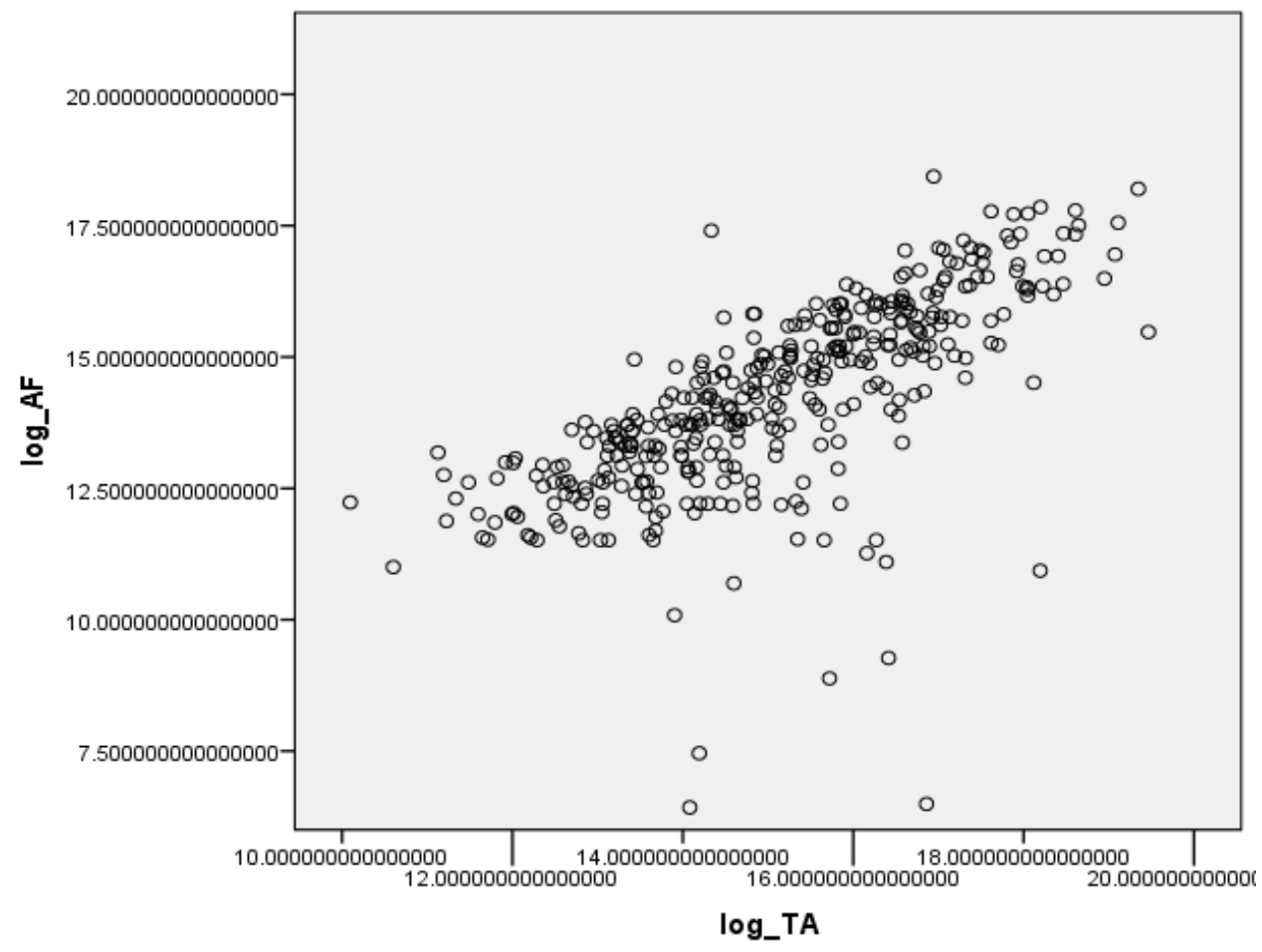

Figure 1B. Log of audit fees vs. log of total assets

\section{Copyright Disclaimer}

Copyright for this article is retained by the author(s), with first publication rights granted to the journal.

This is an open-access article distributed under the terms and conditions of the Creative Commons Attribution license (http://creativecommons.org/licenses/by/4.0/) 